are amply demonstrated in the high standard of ORYX and the multifarious subjects with which it deals. He has been the architect of many a successful conservation project, the best known being "Operation Noah" and "Operation Oryx". During his tenure of office he has witnessed farreaching changes in the set-up of the forces of conservation which have had an impact, at times frustrating, on the activities of the Society. No better person could have been found to further the good work of Edward North Buxton, Geoffrey Dent, Geoffrey Vevers, J. Stevenson-Hamilton, C. W. Hobley, and H. G. Maurice, and the award of the O.B.E. was well deserved recognition of his valuable services. In taking farewell of one who has served the Society so conscientiously and well and in thanking him most gratefully for all he has done, we also express our appreciation and gratitude for the unassuming and willing help and constant encouragement he has always had from his wife.

\title{
IUCN Nairobi, 1963
}

By R. S. R. FITTER

TWO striking statements highlighted the underlying theme of the Eighth General Assembly and Ninth Technical Meeting of the International Union for Conservation of Nature and Natural Resources held at Nairobi, Kenya, from 12th to 24th September, 1963. Stuart Udall, United States Secretary of the Interior, described the world wildlife situation as a race between conservation and catastrophe. Sir Julian Huxley, doyen of world conservationists and a Vice-President of the Fauna Preservation Society, declared boldly that man is in danger of becoming the cancer of his own planet, instead of its lord and master, or better still its benevolent guide. The Assembly was attended on behalf of the Fauna Preservation Society by Lt.-Col. C. L. Boyle, the Secretary, accompanied by Mrs. Boyle, and by Mr. R. S. R. Fitter, Secretary designate, and Mrs. M. S. Fitter, Editor designate of ORYX. Other members of Council who were present were Dr. Fraser Darling, Sir Hugh Elliott, and Mr. Peter Scott. The first presentation of the J. C. Phillips Medal for distinguished service to international wildlife conservation since the previous General Assembly was made to Mr. E. M. Nicholson, Director-General of the Nature Conservancy.

The subjects discussed at the Technical Meeting were arranged under the general heading of " The ecology of man in the tropical environment ". At the end of the Assembly, Professor François Bourlière (France) succeeded Professor Jean Baer (Switzerland) as President of the Union, and Mr. van der Elst (Belgium), Dr. Shawki (Sudan), and Dr. E. B. Worthington (U.K.) became Vice-Presidents. Among the forty resolutions passed were one calling for a conference in 1965 on animals and plants threatened with extinction; one calling for the strict protection of the lowland gorilla in at least one national park in each country of West Africa where it is found; one calling for the preservation of the red colobus monkey and Livingstone's antelope in Zanzibar ; one urging the Governments of Indonesia and Malaysia to implement the legislation that protects 
the birds of paradise; and one urging the greatest care in the use of chemical pesticides within national parks and nature reserves. The next meeting of IUCN will be held in Switzerland in 1966.

\section{KENYA PLEDGE TO CONSERVATION}

During the IUCN Conference in Nairobi, the Government of Kenya issued this statement, which was widely welcomed, pledging itself to the conservation of the country's natural resources and wildlife :

"The natural resources of this country-its wildlife which offers such an attraction to visitors from all over the world, the beautiful places in which these animals live, the mighty forests which guard the water catchment areas so vital to the survival of man and beast-are a priceless heritage for the future. The Government of Kenya, fully realizing the value of its natural resources, pledges itself to conserve them for posterity with all the means at its disposal. We are confident of the co-operation of the other Governments of East Africa in this important task but, at present, we are unable, unaided, to provide the specialist staff and money which are necessary. We therefore invite other nations, and lovers of nature throughout the world, to assist us in honouring this solemn pledge."

The statement was signed by $\mathrm{Mr}$. Kenyatta as Prime Minister, as well as by the Ministers of Natural Resources, and of Information, Broadcasting and Tourism.

\section{Fifty Thousand Leopards to Make Coats and Handbags}

THE present fashion for leopardskin coats, hats, and handbags is seriously depleting leopard stocks in East Africa and threatening its future as a wild animal there. The fashion has led to the development of a huge illicit trade in leopard skins based on a highly organised network of poaching and smuggling. The only hope of stopping this abominable trade seems to be to knock the bottom out of the market by killing the demand. The Fauna Preservation Society has written to all the leading fashion writers in this country stating the facts about the leopard situation, and also to the chairman and members of the Incorporated Society of London Fashion Designers asking for their help in discouraging the fashion.

A full-sized leopardskin coat takes from five to seven skins, and it is estimated that 50,000 skins a year are being sent from East Africa alone to supply the trade. Of these only about 500 animals are killed legally, by licensed shooting, or by game wardens on control work. The rest are poached, by methods usually involving cruelty. Nooses and large box traps baited with meat are commonly used, involving the slow death of the leopard in the sun, or perhaps spearing when it is near death ; springjawed traps are less widely used because they tend to spoil the skin ; baits are doped with poison, including cattle dip, and the animals die in agony. 